\title{
Implementasi Metode Topsis Dalam Penentuan Kelas Siswa Tunagrahita
}

\author{
Ommi Alfina', Fitriana Harahap ${ }^{2}$ \\ UNIVERSITAS POTENSI UTAMA \\ Jl. KL. Yos Sudarso KM 6,5 No 3 A Tj. Mulia Medan \\ 1ny.aroen@gmail.com, 2fitrianaharahap1@gmail.com
}

\begin{abstract}
Children with special needs are children born with special needs that are different from humans in general so they need special services. Someone with intellectual barriers has been ensured that he is a person with mental retardation. In general, mentally retarded children are children who have deficiencies in terms of intellectual function in real terms and together with that it also has an impact on deficiencies in terms of adaptive behavior. Children have the right and opportunity to develop according to their potential, especially in the field of education. "Children who have physical or mental disabilities are given equal opportunities and accessibility to get an ordinary / extraordinary education." Handling the learning of mentally retarded children depends on the difficulties experienced by each individual. The role of the teacher in handling this is very important. Teachers as mentors in class need to view mentally retarded students with varying conditions about their potential or abilities individually. This study aims to apply the TOPSIS method in determining the class of mentally retarded students. The Topsis method is able to provide the best alternative with assessment criteria so that the results to be achieved will immediately be able to determine the class according to the individual abilities of mentally retarded students.
\end{abstract}

Keywords: Tunagrahita, Decision Support System, Topsis

\begin{abstract}
Abstrak- Anak berkebutuhan khusus merupakan anak yang dilahirkan dengan kebutuhan-kebutuhan khusus yang berbeda dari manusia pada umumnya sehingga membutuhkan pelayanan khusus. Seseorang dengan memiliki hambatan kecerdasan sudah dipastikan bahwa ia adalah penyandang tunagrahita. Secara umum anak tunagrahita adalah anak yang memiliki kekurangan dalam hal fungsi intelektualnya secara nyata dan bersamaan dengan itu berdampak pula pada kekurangan dalam hal perilaku adaptifnya. Anak mempunyai hak dan kesempatan untuk berkembang sesuai dengan potensinya terutama dalam bidang pendidikan. "Anak yang menyandang cacat fisik atau mental diberikan kesempatan yang sama dan aksesibilitas untuk memperoleh pendidikan biasa/luar biasa". Penanganan pada pembelajaran anak tunagrahita tergantung pada kesulitan yang dialami setiap individu. Peran guru dalam penanganan ini sangat penting. Guru sebagai pembimbing dikelas perlu memandang siswa tunagrahita dengan kondisi yang bervariasi tentang potensi mereka atau kemampuannya secara individual. Penelitian ini bertujuan untuk menerapkan metode TOPSIS dalam penentuan kelas siswa tunagrahita. Metode Topsis mampu memberikan alternatif terbaik dengan kriteria penilaian Sehingga dengan hasil yang akan dicapai akan langsung dapat menentukan kelas yang sesuai dengan kemampuan individu siswa tunagrahita.
\end{abstract}

Kata kunci: Tunagrahita,Sistem Pendukung Keputusan,Topsis

\section{PENDAHULUAN}

Setiap anak memiliki ciri khas serta kelebihan yang berbeda-beda satu sama lain. Anak dengan kebutuhan khusus merupakan salah satu contoh perbedaan ciri khas dari seorang anak. Perbedaan tersebut harus diapresiasi 
dengan baik oleh individu yang berada di lingkungan anak. Penerimaan yang baik dari lingkungan merupakan salah satu hak yang harus diterimanya. Sayangnya, tidak semua pihak-pihak tersebut menyadari bahwa penerimaan dari mereka akan berpengaruh terhadap kondisi psikis anak. Sebagaimana anak lainnya, Anak Berkebutuhan Khusus (ABK) memiliki hak yang sama untuk bisa bersekolah di sekolah umum, hal ini telah diatur dalam peraturan perundangan Nomor: 20 tahun 2003 tentang Sistem Pendidikan Nasional Indonesia. Menurut Heward, anak berkebutuhan khusus adalah anak yang mempunyai karakteristik berbeda dengan anak pada umumnya tetapi tidak berarti perbedaan tersebut selalu mengarah kepada ketidak mampuan secara mental, emosi atau fisik. Anak berkebutuhan khusus mempunyai perbedaan dalam hal : ciri ciri mental, kemampuankemampuan sensorik, fisik dan neuromaskular, perilaku sosial dan emosional, kemampuan berkomunikasi, maupun campuran dari dua atau lebih hal-hal di atas dari rata-rata anak normal, ia memerlukan perubahan yang mengarah pada perbaikan tugas-tugas sekolah, metode belajar atau pelayanan lainnya, yang bertujuan untuk mengembangkan potensi atau kemampuannya secara maksimal.

Ada beberapa klasifikasi tuna grahita menurut American Association on Mental Deficiency(AAMD). Pertama, Tunagrahita Ringan (Mampu Didik). Anak yang menderita tugrahita ringan mempunyai kemampuan untuk berkembang dalam bidang pelajaran akademik, penyesuaian sosial dan kemampuan untuk bekerja, mampu melakukan penyesuaian dengan lingkungan yang lebih luas, dapat mandiri dalam masyarakat, mampu melakukan pekerjaan semi trampil dan pekerjaan sederhana. Kedua, Tunagrahita Sedang (Mampu Latih), dapat belajar keterampilan sekolah untuk tujuan fungsional, mampu mengurus dirinya sendiri (self-help), mampu melakukan penyesuaian sosial dalam lingkungan terdekat, mampu mengerjakan pekerjaan rutin tetapi harus diawasi. Ketiga, Tunagrahita Berat dan Sangat Berat (Mampu Rawat), hampir tidak dapat dilatih untuk mengurus diri sendiri. Ada yang masih mampu dilatih mengurus diri sendiri, hanya mampu berkomunikasi secara sederhana dan dapat beradaptasi dengan lingkungan tetapi sangat terbatas. Berdasarkan latar belakang tersebut peneliti ingin menerapkan tes IQ untuk menetukan kelas siswa pada SLB Musdalifah. Selama ini tidak dilakukan tes untuk siswa tunagrahita sehingga mengakibatkan proses belajar mengajar sedikit terganggu. Karena anak tunagrahita memiliki penanganan yang berbeda beda sesuai dengan kemampuan individu masingmasing. Metode yang digunakan peneliti adalah metode topsis, dimana metode topsis didasarkan pada konsep bahwa alternatif terpilih yang terbaik tidak hanya memiliki jarak terpendek dari solusi ideal positif tetapi juga memiliki jarak terpanjang dari solusi ideal negative[ 1].

\section{METODE PENELITIAN}

\subsection{Sistem Pendukung Keputusan}

Sistem Pendukung Keputusan adalah sebuah sistem yang dimaksudkan untuk mendukung para pengambil keputusan manajerial dalam situasi keputusan semi terstruktur. Sistem pendukung keputusan dimaksudkan untuk menjadi alat bantu bagi para pengambil keputusan untuk memperluas kapabilitas mereka, namun tidak untuk menggantikan penilaian mereka. Sistem pendukung keputusan 
ditujukan untuk keputusan-keputusan yang memerlukan penilaian atau pada keputusan keputusan yang sama sekali tidak dapat didukung oleh algoritma[2].

\subsection{Komponen-komponen Sistem Pendukung Keputusan}

Adapun komponen-komponen dalam sistem pendukung keputusan sebagai berikut [3] :

\subsubsection{Subsistem Manajemen Data}

Subsistem manajemen data terdiri dari elemen berikut ini :

a. Decision Support System (DSS) database adalah kumpulan data yang saling terkait yang diorganisir untuk memenuhi kebutuhan dan struktur sebuah organisasi dan dapat digunakan oleh lebih dari satu orang untuk lebih dari satu aplikasi.

b. Sistem manajemen basis data adalah pembuatan, pengaksesan, dan pembaharuan (update) oleh DBMS yang mempunyai fungsi utama sebagai tempat penyimpanan, mendapatkan kembali (retrieval) dan pengontrolan.

c. Direktori merupakan sebuah katalog dari semua data di dalam basis data.

d. Query Facility, yang menyediakan fasilitas akses data. Fungsi utamanya adalah untuk operasi seleksi dan manipulasi data dengan menggunakan model-model yang sesuai dari model management.

\subsubsection{Subsistem Manajemen Model}

Subsistem manajemen model terdiri atas elemen-elemen berikut ini :

a. Basis Model

Berisikan model-model seperti manajemen keuangan, statistik, ilmu manajemen yang bersifat kuantitatif yang memberikan kapabilitas analisis pada sebuah SPK. Model Strategis digunakan untuk mendukung manajemen puncak dalam menjalankan tanggung jawab perencanaan strategis.

b. Sistem Manajemen Basis Model

Merupakan sistem software yang fungsi utamanya untuk membuat model dengan menggunakan bahasa pemrograman, alat SPK dan atau subrutin, dan balok pembangunan lainnya; membangkitkan rutin baru dan laporan; pembaruan dan perubahan model; dan manipulasi model.

c. Direktori Model Peran

Direktori model sama dengan direktori basis data. Direktori model adalah katalog dari semua model dan perangkat lunak lainnya pada basis model. Ia berisi defenisi model dan fungsi utamanya adalah menjawab pertanyaan tentang ketersediaan dan kapabilitas model.

d. Eksekusi Model, Integrasi, dan Prosesor

Perintah Eksekusi model adalah proses mengontrol jalannya model saat ini. Integrasi model mencakup gabungan operasi beberapa model saat diperlukan atau mengintegrasikan SPK dengan aplikasi lain. Sedangkan prosesor model digunakan untuk menerima dan menginterpretasikan berbagai macam instruksi pemodelan.

e. Subsistem Dialog

Komponen dialog SPK adalah perangkat lunak dan perangkat keras yang menyediakan antarmuka untuk SPK. Istilah antarmuka pengguna mencakup 
semua aspek komunikasi antara satu pengguna dan SPK. Cakupannya tidak hanya perangkat lunak dan perangkat keras, tapi juga faktor-faktor yang berkaitan dengan kemudahan pengguna, kemampuan untuk dapat diakses, dan interaksi manusia-mesin.

f. Subsistem Manajemen Knowledge

Banyak masalah tak terstruktur dan bahkan semi terstruktur yang sangat kompleks sehingga solusinya memerlukan keahlian. Oleh karena itu banyak SPK canggih yang dilengkapi dengan komponen manajemen knowledge. Komponen ini menyediakan keahlian untuk memecahkan beberapa aspek masalah dan memberikan pengetahuan yang dapat meningkatkan operasi komponen SPK lainnya.

\subsection{Metode TOPSIS}

Technique for Order Performance of Similarity to Ideal Solution (TOPSIS) merupakan salah satu sistem pendukung keputusan multikriteria. TOPSIS mempunyai prinsip bahwa alternatif yang terpilih harus mempunyai jarak terdekat dari solusi ideal positif dan mempunyai jarak terjauh dari solusi ideal negatif dari sudut pandang geometris dengan menggunkana jarak Euclidean (jarak antara dua titik) untuk menentukan kedekatan relatif dari suatu alternatif [4].

Metode TOPSIS memiliki keuntungan sebagai berikut:

a. Metode Topsis merupakan salah satu metode yang simple dan konsep rasional yang mudah dipahami.

b. Metode Topsis mampu untuk mengukur kinerja relatif dalam membentuk form matematika sederhana.

Tahapan metode Topsis [4][5] :

a. Membuat matriks keputusan yang ternormalisasi.

b. Membuat matriks keputusan yang ternormalisasi terbobot.

c. Menentukan matriks solusi ideal positif dan matriks solusi ideal negatif.

d. Menentukan jarak antara nilai setiap alternatif dengan matriks solusi ideal positif dan negatif.

e. Menentukan nilai preferensi untuk setiap alternatif.

TOPSIS membutuhkan rating kinerja setiap alternatif Ai pada setiap kriteria

Cj yang ternormalisasi, yaitu :

$r i j=\frac{x_{i j}}{\sqrt{\sum_{i=1}^{m} x_{i j} j^{2}}}$

$I=1,2 \ldots . . m ;$ dan $j=1,2, \ldots \ldots . .$.

Solusi ideal positif A+ dan solusi ideal A- dapat ditentukan berdasarkan rating bobot ternormalisasi (yij) sebagai :

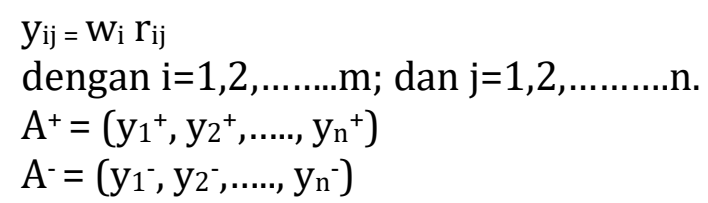


$\mathrm{Y}^{+} \operatorname{maxy}_{\text {ij }}$ jika $\mathrm{j}$ adalah atibut keuntungan

$\mathrm{Y}_{\mathrm{j}}=\left\{\min _{\mathrm{ij}}\right.$;jika ja adalah atribut biaya

$\overline{Y_{j}}=$ miny $_{\mathrm{ij}}$ jikaj adalah atibut keuntungan

max $y_{\text {ij }}$ jjika ja adalah atribut biaya

Jarak antara alternatif Ai dengan solusi ideal positif dirumuskan sebagai :

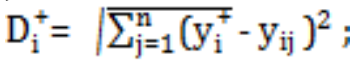

Jarak antara alternatif Ai dengan solusi ideal negative dirumuskan sebagai berikut:

$\left.D_{i}^{-}=\sqrt{\sum_{j=1}^{n}\left(y_{i j}\right.}-y_{I}^{-}\right)^{2} ;$

Menentukan nilai prefensi untuk setiap alternatif :

$V_{i} \frac{D_{i}}{D^{-}+D^{+}}$

Nilai Vi yang lebih besar menunjukkan bahwa alternatif Ai lebih dipilih

\subsection{Anak Tunagrahita}

Tunagrahita (seseorang yang memiliki hambatan kecerdasan) menurut Kustawan, D. (2016) merupakan anak yang memiliki inteligensi yang signifkan berada dibawah rata-rata dan disertai dengan ketidakmampuan dalam adaptasi perilaku yang muncul dalam masa perkembangan. Ia juga mengatakan bahwa anak dengan tunagrahita mempunyai hambatan akademik yang sedemikian rupa sehingga dalam layanan pembelajarannya memerlukan modifikasi kurikulum yang sesuai dengan kebutuhan khususnya. Masyarakat pada umumnya mengenal tunagrahita sebagai retardasi mental atau terbelakang mental atau idiot. Rachmayana, D. (2016) mengemukakakan bahwa tunagrahita berarti suatu keadaan yang ditandai dengan fungsi kecerdasan umum yang berada dibawah rata-rata disertai dengan berkurangnya kemampuan untuk menyesuaikan diri (berperilaku adaptif), yang mulai timbul sebelum usia 18 tahun. Ia juga mengatakan bahwa orang-orang secara mental mengalami keterbelakangan, memiliki perkembangan kecerdasan (IQ) yang lebih rendah dan mengalami kesulitan dalam proses belajar serta adaptasi sosial[6].

\section{HASIL DAN PEMBAHASAN}

Sampel yang digunakan dalam penentuan kelas siswa tunagrahita menggunakan metode TOPSIS menggunakan 6 alternatif dan 5 kriteria. Prosedur perhitungan yang dilakukan adalah :

\subsection{Menetukan nilai relatif terhadap masing-masing alternatif}

Sampel perhitungan untuk masing-masing pengesub dapat dilihat pada tabel 1.

Tabel 1. Nilai alternatif terhadap masing-masing kriteria

\begin{tabular}{|l|l|c|c|c|c|c|}
\hline No & \multicolumn{1}{|c|}{ Nama } & C1 & C2 & C3 & C4 & C5 \\
\cline { 3 - 7 } & & $\begin{array}{c}\text { Berpikir } \\
\text { Verbal }\end{array}$ & $\begin{array}{c}\text { Kemampuan } \\
\text { Numerical }\end{array}$ & $\begin{array}{c}\text { Kecakapan/Ketelit } \\
\text { ian }\end{array}$ & $\begin{array}{c}\text { Berpikir } \\
\text { Menarik }\end{array}$ & $\begin{array}{c}\text { Pemakaian } \\
\text { Bahasa }\end{array}$ \\
\hline 1 & Luthfi Rahman Husin & 60 & 65 & 60 & 60 & 60 \\
\hline 2 & Riski Pratama & 68 & 70 & 70 & 65 & 70 \\
\hline 3 & Lidya Ningrum & 70 & 70 & 70 & 60 & 68 \\
\hline 4 & Muhammad Hanif & 75 & 80 & 70 & 65 & 70 \\
\hline
\end{tabular}




\begin{tabular}{|l|l|c|c|c|c|c|}
\hline No & Nama & C1 & C2 & C3 & C4 & C5 \\
\cline { 3 - 7 } & & $\begin{array}{c}\text { Berpikir } \\
\text { Verbal }\end{array}$ & $\begin{array}{c}\text { Kemampuan } \\
\text { Numerical }\end{array}$ & $\begin{array}{c}\text { Kecakapan/Ketelit } \\
\text { ian }\end{array}$ & $\begin{array}{c}\text { Berpikir } \\
\text { Menarik }\end{array}$ & $\begin{array}{c}\text { Pemakaian } \\
\text { Bahasa }\end{array}$ \\
\hline 5 & Ramadhon & 70 & 70 & 75 & 60 & 68 \\
\hline 6 & Muhammad Riski & 75 & 80 & 70 & 65 & 70 \\
\hline
\end{tabular}

\subsection{Menentukan matriks keputusan ternormalisasi.}

Dalam menentukan matriks keputusan ternormalisasi, nilai tiap kriteria( $\left.\mathrm{x}_{\mathrm{ij}}\right)$ untuk keseluruhan alternatif dijumlahkan kemudian nilai masing-masing criteria tersebut dibagi dengan hasil jumlah kriterianya.

a. Untuk kriteria berfikir verbal $\left(\mathrm{C}_{1}\right)$

$$
\begin{array}{ll}
\mathrm{C}_{1}=\sqrt{60^{2}+68^{2}+70^{2}+75^{2}}+70^{2}+75^{2}=171.10 \\
\mathrm{R}_{11}=\mathrm{X}_{11} / \mathrm{C}_{1}=60 / 171.10 & =0.35 \\
\mathrm{R}_{21}=\mathrm{X}_{21} / \mathrm{C}_{1}=68 / 171.10 & =0.40 \\
\mathrm{R}_{31}=\mathrm{X}_{31} / \mathrm{C}_{1}=70 / 171.10 & =0.41 \\
\mathrm{R}_{41}=\mathrm{X}_{41} / \mathrm{C}_{1}=75 / 171.10 & =0.44 \\
\mathrm{R}_{51}=\mathrm{X}_{51} / \mathrm{C}_{1}=70 / 171.10 & =0.41 \\
\mathrm{R}_{61}=\mathrm{X}_{61} / \mathrm{C}_{1}=75 / 171.10 & =0.44
\end{array}
$$

b. Untuk kriteria kemampuan numerical $\left(\mathrm{C}_{2}\right)$

$$
\begin{array}{ll}
\mathrm{C}_{2}=\sqrt{65^{2}+70^{2}+70^{2}+80^{2}}+70^{2}+80^{2} & =178.12 \\
\mathrm{R}_{11}=\mathrm{X}_{11} / \mathrm{C}_{2}=65 / 171.12 & =0.36 \\
\mathrm{R}_{21}=\mathrm{X}_{21} / \mathrm{C}_{2}=70 / 171.12 & =0.39 \\
\mathrm{R}_{31}=\mathrm{X}_{31} / \mathrm{C}_{2}=70 / 171.12 & =0.39 \\
\mathrm{R}_{41}=\mathrm{X}_{41} / \mathrm{C}_{2}=80 / 171.12 & =0.45 \\
\mathrm{R}_{51}=\mathrm{X}_{51} / \mathrm{C}_{2}=70 / 171.12 & =0.39 \\
\mathrm{R}_{61}=\mathrm{X}_{61} / \mathrm{C}_{2}=80 / 171.12 & =0.45
\end{array}
$$

Dan seterusnya, sehingga didapatkan Tabel 2.

Tabel 2. Matrik Ternormalisasi

\begin{tabular}{|l|l|l|l|l|}
\hline 0.35 & 0.36 & 0.35 & 0.39 & 0.36 \\
\hline 0.40 & 0.39 & 0.41 & 0.42 & 0.42 \\
\hline 0.41 & 0.39 & 0.41 & 0.39 & 0.41 \\
\hline 0.44 & 0.45 & 0.41 & 0.42 & 0.42 \\
\hline 0.41 & 0.39 & 0.44 & 0.39 & 0.41 \\
\hline 0.44 & 0.45 & 0.41 & 0.42 & 0.42 \\
\hline
\end{tabular}

\subsection{Menentukan matriks keputusan normalisasi terbobot}

Sebelum menghitung matrik keputusan normalisasi terbobot, tentukan terlebih dahulu bobot dari masing-masing kriteria. Tingkat kepentingan tiap kriteria dapat dinilai dari range 1 sampai 5, yaitu :

1 : tidak penting

2 : tidak terlalu penting

3 : cukup penting

4 : penting

5 : sangat penting

Nilai bobot awal (w) digunakan untuk menunjukkan tingkat kepentingan relatife dari setiap kriteria. Bobot dari masing-masing criteria tertera pada tabel 3. 
Tabel 3. Bobot Kriteria

\begin{tabular}{|c|l|c|}
\hline No & \multicolumn{1}{|c|}{ Kriteria } & Bobot (W) \\
\hline 1 & Berpikir Verbal & 5 \\
\hline 2 & Kemampuan Numerical & 5 \\
\hline 3 & Kecakapan/Ketelitian & 4 \\
\hline 4 & Berpikir Menarik & 3 \\
\hline 5 & Pemakaian Bahasa & 4 \\
\hline
\end{tabular}

Setelah menentukan bobot dari masing-masing kriteria, maka berdasarkan langkah 1 dan persamaan 2, kita dapat mengitung matrik normalisasi terbobot yaitu :

a. Untuk kriteria berpikir verbal

$$
\begin{array}{ll}
\mathrm{Y}_{11}=\mathrm{W}_{11} * \mathrm{R}_{11}=5^{*} 0.35 & =1.75 \\
\mathrm{Y}_{21}=\mathrm{W}_{11} * \mathrm{R}_{21}=5^{*} 0.40 & =2.00 \\
\mathrm{Y}_{31}=\mathrm{W}_{11} * \mathrm{R}_{31}=5^{*} 0.41 & =2.05 \\
\mathrm{Y}_{41}=\mathrm{W}_{11} * \mathrm{R}_{41}=5^{*} 0.44 & =2.20 \\
\mathrm{Y}_{51}=\mathrm{W}_{11} * \mathrm{R}_{51}=5^{*} 0.41 & =2.05 \\
\mathrm{Y}_{61}=\mathrm{W}_{11} * \mathrm{R}_{61}=5^{*} 0.33 & =2.20
\end{array}
$$

b. Untuk kriteria kemampuan Numerical

$$
\begin{array}{ll}
\mathrm{Y}_{11}=\mathrm{W}_{22} * \mathrm{R}_{11}=5^{*} 0.36 & =1.80 \\
\mathrm{Y}_{21}=\mathrm{W}_{22} * \mathrm{R}_{21}=5^{*} 0.39 & =1.95 \\
\mathrm{Y}_{31}=\mathrm{W}_{22} * \mathrm{R}_{31}=5^{*} 0.39 & =1.95 \\
\mathrm{Y}_{41}=\mathrm{W}_{22} * \mathrm{R}_{41}=5^{*} 0.45 & =2.25 \\
\mathrm{Y}_{51}=\mathrm{W}_{22}{ }^{*} \mathrm{R}_{51}=5^{*} 0.39 & =1.95 \\
\mathrm{Y}_{61}=\mathrm{W}_{22} * \mathrm{R}_{61}=5^{*} 0.45 & =2.25
\end{array}
$$

Dan seterusnya, sehingga didapatkan table 4 .

Tabel 4. Matriks Ternormalisasi Terbobot

\begin{tabular}{|l|l|l|l|l|}
\hline 1.75 & 1.80 & 1.40 & 1.17 & 1.44 \\
\hline 2.00 & 1.95 & 1.64 & 1.26 & 1.68 \\
\hline 2.05 & 1.95 & 1.64 & 1.17 & 1.64 \\
\hline 2.20 & 2.25 & 1.64 & 1.26 & 1.68 \\
\hline 2.05 & 1.95 & 1.76 & 1.17 & 1.64 \\
\hline 2.20 & 2.25 & 1.64 & 1.26 & 1.68 \\
\hline
\end{tabular}

3.4 Menentukan matriks solusi ideal positif dan matriks solusi ideal negative Langkah selanjutnya yaitu menentuka matriks solusi ideal positif dan matriks solusi ideal negatif berdasarkan persamaan 3 dan 4 .

Matriks solusi ideal positif $\left(\mathrm{Y}_{\mathrm{ij}}{ }^{+}\right)$:

$$
\begin{aligned}
& \mathrm{A}^{+}=\left(\mathrm{y}_{1}{ }^{+}, \mathrm{y}_{2}{ }^{+}, \ldots . ., \mathrm{yn}^{+}\right) ; \\
& A^{-}=\left(\mathrm{y}_{1}, \mathrm{y}_{2}, \ldots . ., \mathrm{y}_{\mathrm{n}}^{-}\right) ; \mathrm{Y}_{\mathrm{j}}^{+}=\left\{\begin{array}{r}
\operatorname{maxy} y_{\text {ij }} \text { jika } j \text { adalah atibut keuntungan } \\
\min \mathrm{y}_{\text {ij }} \text { jika ja adalah atribut biaya }
\end{array}\right.
\end{aligned}
$$

Solusi ideal positif dihitung sebagai berikut :

$\mathrm{y}_{1}{ }^{+}=\max \{1.75 ; 2.00 ; 2.05 ; 2.20 ; 2.05 ; 2.20\}=2.20$

$\mathrm{y}_{2}{ }^{+}=\max \{1.80 ; 1.95 ; 1.95 ; 2.25 ; 1.95 ; 2.25\}=2.25$

$\mathrm{y}_{3}{ }^{+}=\max \{1.40 ; 1.64 ; 1.64 ; 1.64 ; 1.76 ; 1.64\}=1.76$

$\mathrm{y}_{4}{ }^{+}=\max \{1.17 ; 1.26 ; 1.17 ; 1.26 ; 1.17 ; 1.26\}=1.26$ 
$\mathrm{y}_{5}{ }^{+}=\max \{1.44 ; 1.68 ; 1.64 ; 1.68 ; 1.64 ; 1.68\}=1.68$

$\mathrm{A}^{+}=\{2.20 ; 2.25 ; 1.76 ; 1.26 ; 1.68\}$

Solusi ideal negatif dihitung sebagai berikut :

$\mathrm{y}_{1}{ }^{-}=\min \{1.75 ; 2.00 ; 2.05 ; 2.20 ; 2.05 ; 2.20\}=1.75$

$\mathrm{y}_{2}{ }^{-}=\min \{1.80 ; 1.95 ; 1.95 ; 2.25 ; 1.95 ; 2.25\}=1.80$

$\mathrm{y}_{3}{ }^{-}=\min \{1.40 ; 1.64 ; 1.64 ; 1.64 ; 1.76 ; 1.64\}=1.40$

$\mathrm{y}_{4}^{-}=\min \{1.17 ; 1.26 ; 1.17 ; 1.26 ; 1.17 ; 1.26\}=1.17$

$\mathrm{y}_{5}{ }^{-}=\min \{1.44 ; 1.68 ; 1.64 ; 1.68 ; 1.64 ; 1.68\}=1.44$

$\mathrm{A}^{-}=\{1.75 ; 1.80 ; 1.40 ; 1.17 ; 1.44\}$.

\subsection{Menentukan jarak antara nilai setiap alternatif}

Menentukan jarak antara nilai setiap alternatif dengan matriks solusi ideal positif dan solusi ideal negatif. Selanjutnya untuk mencari jarak antar alternative dengan matriks solusi ideal positif dapat menggunakan persamaan 5.

arak antara alternatif Ai dengan solusi ideal positif dirumuskan sebagai berikut:

$\mathrm{D}_{\mathrm{i}}^{+}=\sqrt{\sum_{\mathrm{j}=1}^{\mathrm{n}}\left(\mathrm{y}_{\mathrm{i}}^{+}-\mathrm{y}_{\mathrm{ij}}\right)^{2}}$

Jarak antara alternatif Ai dengan solusi ideal negative dirumuskan sebagai berikut :

$D_{i}^{-}=\sqrt{\sum_{j=1}^{n}\left(y_{i I}-y_{I}^{-}\right)^{2} ;}$

Membuat jarak antar nilai terbobot setiap alternatif terhadap solusi ideal positif :

Nilai jarak solusi ideal positif untuk berpikir verbal

$$
\begin{aligned}
D_{1}^{+} & =\sqrt{\begin{array}{c}
(1.75-2.2)^{2}+(1.80-2.25)^{2}+(1.40-1.76)^{2} \\
+(1.17-1.26)^{2}+(1.44-1.68)^{2}
\end{array}} \\
& =0.77
\end{aligned}
$$

$$
\begin{aligned}
\mathrm{D}_{2}^{+} & =\sqrt{\begin{array}{c}
(2.0-2.22)^{2}+(1.95-2.25)^{2}+(1.64-1.76)^{2} \\
+(1.26-1.26)^{2}+(1.68-1.68)^{2}
\end{array}} \\
& =0.38
\end{aligned}
$$

$\mathrm{D}_{3}^{+}=0.37$

$\mathrm{D}_{4}^{+}=0.12$

$\mathrm{D}_{5}^{+}=0.35$

$\mathrm{D}_{6}^{+}=0.12$

jarak solusi solusi ideal negatif :

$$
\mathrm{D}_{1}^{-}=\sqrt{\begin{array}{c}
(1.75-1.75)^{2}+(1.80-1.80)^{2}+(1.40-1.40)^{2} \\
+(1.17-1.17)^{2}+(1.44-1.44)^{2}
\end{array}}
$$


$=0$

$\mathrm{D}_{2}^{-}=0.61$

$\mathrm{D}_{3}^{-}=0.46$

$\mathrm{D}_{4}^{-}=0.73$

$\mathrm{D}_{5}^{-}=0.53$

$\mathrm{D}_{6}^{-}=0.73$

\subsection{Mencari nilai preferensi untuk setiap alternatif}

Langkah terakhir dalam perhitungan TOPSIS adalah mencari nilai preferensi untuk setiap alternatif diberikan sesuai dengan persamaan 7.

$V_{i} \frac{D_{i}}{D^{-}+D^{+}}$

Nilai $V_{i}$ yang lebih besar menunjukkan bahwa alternatif $A_{i}$ lebih dipilih.

Menghitung nilai preferensi :

a. Nilai preferansi bernama Luthfi Rahman

$$
\mathrm{V} 1=\frac{0}{(0+0.77)}=0
$$

b. Nilai preferansi bernama Riski Pratama

$$
\mathrm{V} 2=\frac{0.61}{(0.61+0.38)}=0.62
$$

c. Nilai preferansi bernama Lidya Ningrum

$$
\mathrm{V} 3=\frac{0.46}{(0.46+0.37)}=0.55
$$

d. Nilai preferansi bernama Muhammad Hanif

$$
\mathrm{V} 4=\frac{0.73}{(0.73+0.12)}=0.86
$$

e. Nilai preferansi bernama Ramadhon

$$
\mathrm{V} 5=\frac{0.53}{(0.53+0.35)}=0.60
$$

f. Nilai preferansi bernama Muhammad Riski

$$
\text { V } 6=\frac{0.73}{(0.73+0.12)}=0.86
$$

\section{KESIMPULAN}

Berdasarkan hasil penelitian yang telah dilakukan dapat diambil kesimpulan sebagai

berikut:

a. Kriteria dasar yang dapat dijadikan standar penentuan kelas siswa tunagrahita adalah: Berpikir Verbal, Kemampuan Numerical, Kecakapan/Ketelitian, Berpikir Menarik, Pemakaian Bahasa.

b. Hasil dari perhitungan dengan menggunakan TOPSIS didapatkan penentuan kelas siswa tunagrahita ringan dengan nilai preferensi relatif untuk setiap alternatifnya sebesar 0.86 atas nama siswa Muhammad Hanif , Muhammad Riski, riski pratama dan Ramadhon. Kelas siswa tunagrahita berat dengan nilai 
preferensi relatif untuk setiap alternatifnya sebesar 0 atas nama siswa Luthfi Rahman.

Untuk menyempurnakan sistem yang telah dibuat ini diberikan saran :

a. Perlu dilakukannya perbandingan hasil perangkingan antara metode TOPSIS dengan metode perangkingan yang lain untuk mendapatkan efektifitas hasil perangkingan yang lebih baik.

b. Aplikasi Sistem Penunjang Keputusan ini dapat membantu pihak sekolah untuk menentukan kelas siswa tunagrahita dengan cepat dan tepat.

c. Aplikasi Sistem Penunjang Keputusan dapat diterapkan berbasis web.

\section{UCAPAN TERIMA KASIH}

Penulis mengucapkan terimakasih kepada Kementerian Riset Teknologi Dan Pendidikan Tinggi Republik Indonesia (KEMENRISTEKDIKTI) yang telah memberi dukungan financial terhadap penelitian ini.

\section{DAFTAR PUSTAKA}

[1] Elyza Gustri Wahyuni, Ananto Tri Anggoro "“ Sistem Pendukung Keputusan Penerimaan Pegawai dengan Metode TOPSIS" Jurnal Sains, Teknologi dan Industri, Vol. 14, No. 2, Juni 2017, pp.108 - 116 ISSN 1693-2390 print/ISSN 2407-0939 online.

[2] Ritonga, Siti Kholijah, 2013, Sistem Informasi Penilaian Kerja Karyawan Menggunakan Metode Technique for Other References bySimilarity to Ideal Solution (TOPSIS),http://www.lshk.or.id/uu/4225.pdf, diakses pada tanggal 5 Januari 2018.

[3] Bunga Annete Benning dkk, "SISTEM PENDUKUNG KEPUTUSAN PEMBELIAN PERANGKAT KOMPUTER DENGAN METODE TOPSIS (Studi Kasus: CV. Triad)" Jurnal Informatika Mulawarman, Vol. 10 No. 2 September 2015.

[4] Agus Perdana Windarto, "IMPLEMENTASI METODE TOPSIS DAN SAW DALAM MEMBERIKAN REWARD PELANGGAN "Kumpulan jurnaL Ilmu Komputer (KLIK) Volume 04, No.01 Februari 2017 ISSN: 2406-7857.

[5] Slamet Hidayat dkk, "SISTEM PENDUKUNG KEPUTUSAN PEMILIHAN GURU TELADAN MA AL MUBAROK BATU RAJA MENGGUNAKAN METODE TOPSIS" Jurnal TAM (Technology Acceptance Model) Volume 6, Juli 2016.

[6] SITI FATIMAH MUTIA SARI dkk, "PENDIDIKAN BAGI ANAK TUNA GRAHITA (STUDI KASUS TUNAGRAHITA SEDANG DI SLB N PURWAKARTA)" Jurnal Penelitian \& PKM Vol 4,Juli 2017, No: 2 Hal: 129 - 389 ISSN2442-448X (p), 2581-1126 (e). 